\title{
As diferentes facetas da conexão via celular
}

\author{
Thaísa Cristina Bueno
}

WINOCUR, R.

\section{Robinson Crusoe ya tiene celular:}

La conexión como espacio de control

de la incertidumbre.

México: Siglo XXI, 2009.

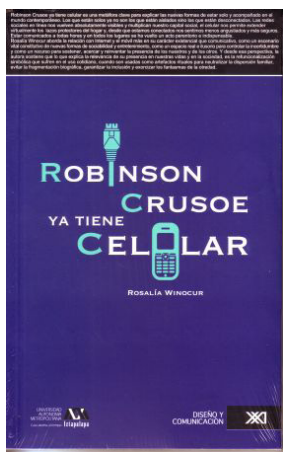

Resumo: A proposta desta resenha é apresentar o livro Robinson Crusoe ya tiene celular: la conexión como espacio de control de la incertidumbre, da escritora mexicana Rosalía Winocur, lançado pela editora Siglo XXI, em 2009. A obra, ainda sem tradução para o português, está disponível para download na internet. O texto trata das mudanças que a conexão das redes sociais por meio do celular trouxe para as relações dos jovens em diferentes ambientes e grupos.

Palavras-chave: comunicação interpessoal; celular; redes sociais.

Abstract: The different facets of mobile connection - The purpose of this review is to present the book Robinson Crusoe ya tiene celular: la conexión como espacio de control de la incertidumbre (Robinson Crusoe already has a cell phone: the connection as a space for controlling uncertainty), by Mexican writer Rosalía Winocur, published by Siglo XXI in 2009. The book, not yet translated into Portuguese, is available for download from the Internet. It discusses the changes that the mobile connection of social networks through cell phones has brought about in the relationships of young people in different environments and groups.

Keywords: interpersonal communication; mobile; social networks. 
Muito tem sido falado sobre as mudanças que as tecnologias trazem nas relações sociais. Já é quase senso comum que redes sociais, celulares conectados, plataforma de interação e demais dispositivos via internet alteraram, em algum grau, a forma como vemos e nos posicionamos no mundo. Mas, no emaranhado de discussões e publicações que tratam do assunto, a escritora mexicana Rosalía Winocur traz, se não uma inovação, um olhar distinto sobre o tema. Com uma linguagem simples e baseada em descrições e entrevistas a autora busca explicar o processo que transformou o aparelho celular no que chama de "novo cordão umbilical" da sociedade. Em outras palavras, tenta entender como esse dispositivo tornou-se tão importante e indispensável no cotidiano.

Em Robinson Crusoe ya tiene celular: la conexión como espacio de control de la incertidumbre a autora faz uma descrição minuciosa dessas mudanças numa perspectiva etnográfica da relação da sociedade com esses recursos, tendo como ponto de partida diferenças entre gerações e entre os que têm mais ou menos condições de adquirir e desfrutar desses aparatos tecnológicos.

O livro, lançado em 2009 pela editora Siglo XXI, ainda não tem tradução para o português, mas pode ser encontrado em formato de e-book para download na internet. Ao todo são 168 páginas que tratam dos aspectos sociais nas redes de computador, com foco em relações interpessoais, tecnologia e civilização.

A pesquisa contribui para olharmos a relação da sociedade com a tecnologia do ponto de vista latino-americano. Por isso, os exemplos que retratam a forma como os sujeitos apropriam-se e dão significações para o objeto cotidiano que, em última análise, teria sido pensado para fazer e receber ligações, nos pareça tão familiar. Embora trate especificamente de comunidades mexicanas, muitas angústias e modos de uso nessa relação entre homem e máquina são partilhadas na mesma medida pelos usuários, pesquisadores ou curiosos brasileiros.

Winocur tem se firmado no âmbito acadêmico pelo olhar etnográfico com que trata o uso das tecnologias. Seus estudos humanizam, se assim podemos dizer, a incorporação da tecnologia na vida ordinária. Da mesma autora encontramos outros textos importantes nessa mesma ótica, como "Internet em la vida cotidiana de los jóvenes", da Revista Mexicana de Sociologia; o "Apropriación de Internet y la computadora em sectores populares urbanos" e "Los unos y los otros. Inmigrantes y nativos em el mundo de las TICs", publicados no Anuário Antropológico da Universidade de Brasília.

No livro em questão, a autora mantém o estilo e divide a publicação em sete capítulos, todos narrando perspectivas distintas da ideia de conexão, sendo esta um meio simbólico de pertencimento ou um espaço de vida entre os jovens. Há ainda discussões sobre a conexão como lugar de visibilidade, manipulação da biografia e local de relação familiar. Por fim, ainda trata da conexão como campo de conflitos e, por último, como modelo de inclusão social das classes mais pobres.

No montante de probabilidades, o livro tem como foco principal o uso do celular como ferramenta de navegação. Não é um olhar que entende esse dispositivo como mais 
um apetrecho que nos mantém conectados às rede social em si, mas que indaga como esta relação de interação foi modificada a partir do momento em que a navegação abandonou o ponto fixo do computador e ganhou a mobilidade e a ubiquidade no dispositivo móvel. Basilar na obra está a ideia de que as redes sociais não podem ser reduzidas a ferramentas de informação e comunicação, mas de refuncionalização simbólica do comportamento cotidiano. "Las redes sociales on line nos vuelven absolutamente visibles y multiplican nuestro capital social, el celular nos permite extender virtualmente los lazos protectores dei hogar, $Y$, desde que estamos conectados nos sentimos menos solos, y más seguros. (p. 13)".

Enfim, o livro busca uma abordagem de uso da rede e dos aparatos móveis mais em termos de seu caráter existencial que instrumental. No estudo sobre jovens, por exemplo, mostra que não é a tecnologia que marca o limite entre o que se pode e não se pode fazer com ela, ou entre o mundo dos adultos e o mundo dos jovens, mas a sua experiência no mundo simbólico, afinal a incorporação de qualquer meio é também mediada pelas experiências anteriores.

Didaticamente podemos resumir os capítulos do livro da seguinte forma: o primeiro vai tratar de como o telefone móvel torna-se uma peça-chave para manter a coesão familiar e mostra-se como uma ferramenta para fortalecer os vínculos afetivos. O capítulo que segue retrata a relação dos jovens com as tecnologias, todas as horas e em todos os lugares. A proposta é de descrever como essa geração tem incorporado o celular às suas vidas. Em seguida o assunto é identidade. Nesse capítulo a autora mostra as mudanças no modo tradicional de socialização e como redes, celulares e comunidades virtuais legitimam novas atitudes de inclusão social e forjam identidades.

O quarto capítulo retrata o uso destes dispositivos como fontes de consolo para aliviar o sofrimento social da distância e da solidão e sua função de gerar sentimentos de presença. Em seguida mostra como esses recursos suprem a instabilidade da ideia de desterritorialização e reconfiguram o conceito de espaço doméstico. O capítulo seis traça um panorama das diferentes formas de uso da ferramenta por pessoas de gerações diferentes, em particular pais e filhos. Por fim, no último capítulo a autora trata da tecnologia como forma de acesso aos bens culturais pelas camadas mais desfavorecidas.

Entre distinções entre os menos familiarizados com as tecnologias e os hiperconectados, o que a obra resume é que, sim, de alguma forma estamos todos ligados. A novidade é que nesse livro ela busca narrar as distintas formas de se relacionar com essa realidade.

Thaísa Cristina Bueno é professora do curso de Jornalismo da Universidade Federal do Maranhão, mestre em Letras pela UFMA e doutoranda em Comunicação pela PUC-RS. thaisabu@gmail.com 